\title{
Efficiency of Social Protection of the Rural Population in the United Territorial Community
}

\author{
By Oksana Samborska
}

\begin{abstract}
Social defense exists in the developed countries of the world long time, and a large value is spared to the special attitude toward national minorities. The necessity of social defence purchased wide application in the end XIX and beginning of XX of century, includes the different types of defence of citizens in case of temporal loss of capacity for diverse reasons, unemployment, professional diseases, industrial accidents, pension system. This system is the complex of socio-economic and legal guarantees of every citizen of country. Social defence of population is called to create the normal terms of residence and stay of citizens in a middle a country, and is priority direction of realization of social politics.
\end{abstract}

Keywords: social protection, minimum payments, state policy, community

\section{Introduction}

In the research and foreign scientists of Bazulevuch V.D., Balastruk L.O., Boreska N.P., Kulichuskuy B.V. investigate the question of local self-government in Ukraine expose essence of concept "social defence", approaches in relation to their choice.

State, that provides to the citizens and persons that are on her territory on legal grounds, deserving standard of living and free development, name social. Such state creates the system of social defence, that embraces the system of social security, social guarantees, social help, system of financing of the pension system on age, different types of urinate, indemnifications medical and other social services. The separate functions of the state in a social sphere are delegated to the state institutes: pension fund, Fund of social security, social growth Fund, Fund from the temporal loss of capacity, Fund of employment and different funds is created at enterprises.

By the universal method of financing of social defense of population - there is social security, built on principles of solidarity of generations, parity and redistribution of money, from capable of working persons to disabled, social security which is financial basis of realization of right for citizens on social defense. The term "social security" means one of the forms of social protection of citizens, officially enshrined in the international Covenant on economic, social and cultural rights, adopted by the UN General Assembly on 16 December 1966 [5]. In article 9 of that document States that "the States participating in this Pact will determine the right of everyone to social security, including social insurance.

This term is used in the concept of social security of the population of Ukraine approved 
by the Verkhovna Rada of Ukraine December 21, 1993 (On approval of the subsistence level for, 2018...). However, in the Constitution, namely, article 46 of the uses already mentioned, the term "social protection". From the contents it follows that "social protection" is a broader concept and includes the concept of "social security", which is part of the social protection system and performs the function of accumulation and distribution of funds for social protection intended for social assistance payments social insurance and so on. Social security includes pensions and various types of benefits (for temporary disability, pregnancy and childbirth, to care for a child up to 3 years, to care for a sick child, on burial assistance to disabled persons, the income is less than the established government traits of neediness). Social security also provides assistance in kind (services disabled, elderly in institutions, boarding schools, homes) (Law of Ukraine: On the State Budget of Ukraine for 2019...). Prerequisites for the implementation of social protection, equality or income inequality.

Factors of disparities the following:

1) differentiation of salaries depending on ability, education, professional experience;

2) uneven distribution of the ownership of securities and real estate;

3) luck, fortune, risk, personal communication.

Reducing inequalities in the distribution and redistribution of income, the state provides through the tax system and transfers, this contributes to the tax system. In almost all countries there are programs of social insurance and public assistance to the poor, which provide insurance according to the age, incapacity for work, loss of employment, the supplemental assistance program: medical insurance, assistance to large families, granting benefits. The policy of redistribution of income is justified in the long term, as it gives the opportunity for the poor to receive education and to achieve some success.

The most important means by which the state distributes and redistributes domestic product is the state budget. After approval, the State Budget enters into force a law in which all levels are compiled and executed in accordance with the budget classification. Budget classification is the only international system of functional grouping of budget revenues and expenditures on homogeneous grounds; it provides an opportunity to compare budget data of different levels, allows to determine the nature of regulatory actions of the state on revenue and areas of use of funds received.

The main source of formation of funds of obligatory state social insurance defined insurance contributions of insurers - employers and insured persons (except the fund of social insurance against accidents at work and occupational diseases of Ukraine, to which contributions paid only by employers), the provision of the state budget; the amount of financial sanctions applied to the enterprises, establishments, organizations and physical persons for violation of the established procedure of payment of insurance premiums and use of funds, and amounts of administrative fines imposed on officials and citizens for such violations; the profit earned from temporarily idle funds, including reserve funds in the Deposit account; charitable contributions of enterprises, institutions, organizations and individuals; other income in accordance with the legislation of Ukraine.

The market economy cannot provide an equitable distribution of income, which leads to their differentiation, resulting in part of the population is below the poverty line, therefore there is a need social protection from the state. Social protection is a state 
responsibility to the citizens and is a complex of economic, social and legal measures and set of institutions that ensure equal opportunities for all to maintain a certain standard of living, as well as support for individual social groups. It is a complex of legislated safeguards against destabilizing factors. Social security includes a system of measures that protect any citizen from economic and social degradation caused by unemployment, sickness, occupational injury, childbirth, disability, old age, and provision of medical services and benefits to families with children. To reduce the negative impact of such factors on the living standards of certain segments of the population and adequate social protection. This assignment is done via two functions - medical and safety.

Social protection system includes three entities: the state, legal entities and citizens. Part of the activities for all members of society, and the rest are addressed to different social groups. The first group of activities is to provide opportunities for each person to use their abilities and generate income, the official definition of a living wage, the protection of consumer interests, indexation of incomes. The second group of measures of social protection for certain population groups, particularly the unemployed, pensioners, the disabled, veterans of labor and military service, families with children, orphans, internally displaced persons and refugees affected by disasters. Social protection system is based on the following principles: universality, accessibility, diversity, adequacy to the level of economic development of the country. Constituents of the social protection system is reflected in Fig. 1.

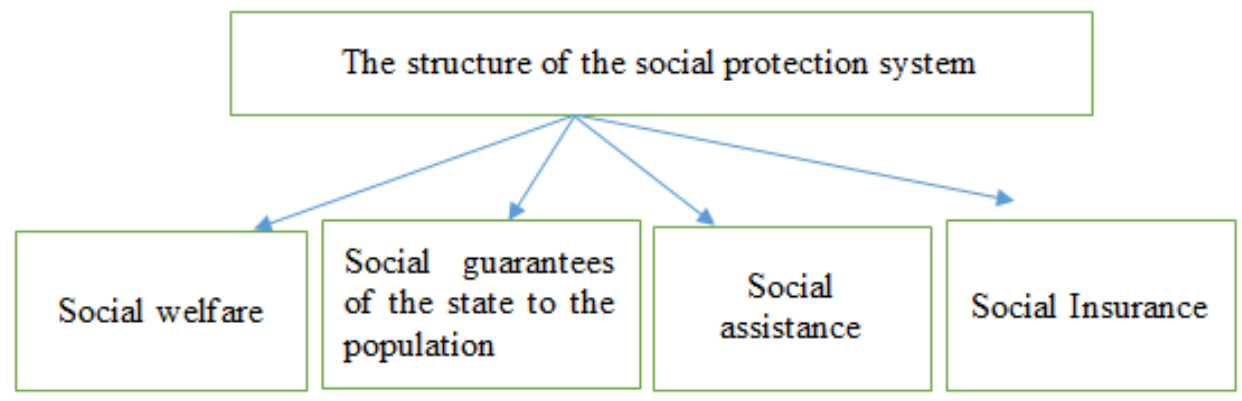

Fig. 1. Components of the social protection system

The right to social security is a constitutional right in Ukraine is guaranteed by the basic law, namely the Constitution of Ukraine. The social security system includes pensions, assistance during pregnancy and childbirth, helping families which have children with disabilities, assistance in the care of the minor child and the like.

Pensions are regular cash payments provided to citizens upon reaching a certain age, in case of disability and loss of breadwinner, and for years of service and special merits before the state. Distinguish between labor and social pensions. Labor are old-age pensions, for disability, loss of breadwinner and for years of service. Some categories of citizens to a pension on preferential terms that is regulated by legislation. In addition to pensions, appointed by and social. they have citizens who are not entitled to a retirement pension. Conditions, procedure for accrual and amount of pensions of all types in our country are regulated by the Law "On Pensions". Social security also includes the payment of benefits to working citizens. This is assistance in case of temporary disability, 
pregnancy and childbirth. Particular attention is paid to assistance to families with children, one-time assistance at the birth of a child, monthly assistance for its upbringing. The second component of the system of social protection of the population is the social guarantees of the state - the realization by the state of the constitutional rights of citizens to receive the most important social goods and services. They are obtaining a profession, labor income, employment, continuous retraining and professional growth of workers to maintain their competition in the labor market, the protection of fundamental human rights. Among the main social guarantees - the right of citizens to choose a place of work and professional activity, the minimum wage and pension, one-time assistance at the birth of each child, the minimum amount of unemployment benefits.

An important place in the system of social protection is occupied by social assistance - it is the care of citizens in need of support, low income and reaching a certain age, assistance is provided in the form of cash and in-kind benefits. The housing subsidy program, since 1995, has become the first market-type social program in the country and provides targeted protection to the population, both disabled and war veterans, of which there are about 4.5 million in Ukraine. One of the areas of social assistance, which has a tendency to expand, is the creation of nursing homes for the elderly. A form of social assistance is spreading, such as the creation of territorial centers for the care of single elderly people.

An integral element of the social protection system is social insurance. It is a system of full or partial financial reimbursement to individuals of certain life risks: temporary disability, old age, invalidity, loss of breadwinner. Social insurance only includes social risks, its purpose is insurance cover these types of risks, such as disability due to illness, accident, old age, job loss, and the like. These types of risk are widespread, are social because it is mainly determined by social conditions and, as a rule, from each individual are independent. This risk is taken into account in advance, and the related financial charges are allocated among all participants of insurance. Depending on the form of the following types of insurance: pension (security in old age), medical (in case of disease, disability from accident at work), unemployment (job loss for reasons beyond the employee's reasons). For each of the types of risk insurance may be voluntary or mandatory. Social insurance includes not only monetary payments and compensation, but also certain services, treatment, rehabilitation and prevention. Financial resources for social insurance are formed mainly by contributions of citizens who are insured, and employers. In the countries with developed market economy, social insurance is already widespread, this pension insurance, medical insurance, unemployment insurance.

Social protection creates guarantees of assistance in case of social risks that any citizen may experience during his life: illness, disability, injury, old age, loss of a breadwinner, unemployment, migration, etc. Covers social security, social insurance and social assistance (support), a set of actions aimed at providing assistance during life crises, implemented by the state through social policy. 


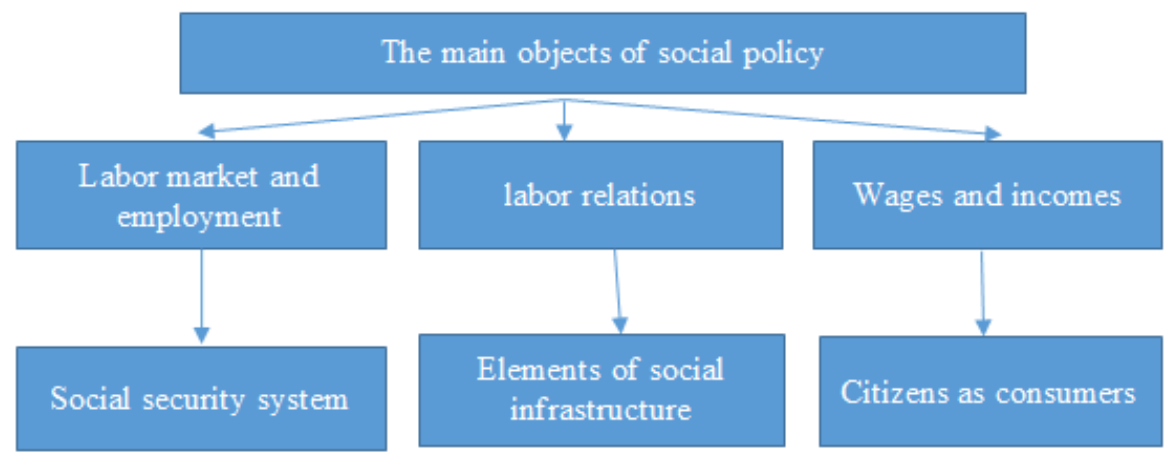

Fig. 1.2. Objects of social policy of the state

Social policy:

- activities of the state to create and regulate the socio-economic living conditions of society in order to improve the welfare of members of society, eliminate the negative consequences of market processes, ensure social justice and socio-political stability of the country;

- a system of legal, organizational, regulatory, control measures of the state in order to reconcile the goals of a social nature with the goals of economic growth.

- These are socio-economic measures of the state, enterprises, local authorities, which are aimed at protecting the population from unemployment, inflation, devaluation of labor savings (Bazulevuch V.D., 2004...).

State regulation of social processes - the influence of public authorities through various means (forms, methods, and tools) for the development of social relations, conditions of life and labour of the population.

Social policy includes:

regulation of social relations in society, the regulation of conditions of interaction of economic agents in the social sector (including between employers and hired labor);

- the problem of unemployment and ensuring effective employment;

- the distribution and redistribution of incomes;

- formation of incentives for highly productive social labour and provision of social guarantees for the economically active part of population;

- creation of system of social protection of the population;

- development of elements of social infrastructure (educational institutions, health care, science, culture, sports, housing and communal services and the like);

- protection of the environment.

An important feature of a socially oriented state is not only to take into account, but also to promote the interests of all social groups and strata of the population, strengthening on this basis the harmony and unity of the people. Protecting the principles of social justice, the Constitution guarantees equal conditions for the development of each individual, the possibility of realizing their abilities for their own and public benefit. The socially oriented state seeks to establish cooperation between different parts of society and imposes numerous socio-economic responsibilities not only on itself but also on entrepreneurs and local governments. Social services are being created, which generally 
form a system of social protection for citizens. In the Constitution of Ukraine stipulates: "Citizens have the right to social protection, which includes the right to provide them in case of full, partial or temporary disability, loss of breadwinner, unemployment due to circumstances beyond their control, as well as in old age and in other cases provided by law» (Bazulevuch V.D., 2004...).

This right is provided by the obligatory state social insurance at the expense of insurance contributions of citizens, enterprises, institutions and organizations, as well as budgetary and other state, communal, private institutions to support the disabled. The implementation and financing of these constitutional norms is carried out through the formation of a certain social policy of the state and relies mainly on state support. At the same time, the introduction of economic reforms, freedom of enterprise, free choice of employment, price liberalization, regulation of wages through tariff agreements necessitated the development of an appropriate mechanism for implementing state social policy, which would effectively cover all its subjects.

The concept of social security of the population of Ukraine was approved by a resolution of the Verkhovna Rada of Ukraine in December 1993. It provided that citizens working for hired labor, members of their families and disabled persons have the right to social security. Self-employed citizens, as well as entrepreneurs, creative workers, members of cooperatives, and farmers, are entitled only to the social guarantees in which they participate.

In accordance with the Law of Ukraine "On Voluntary Association of Territorial Communities", the Kunka Territorial Community was established. In the elections held on October 25, 2015, 22 deputies of the village council were elected, including 13 men, 9 women, and the village head. The total area of the community is $451,638 \mathrm{~km} .{ }^{2}$. The population of the community is 4376 people (423 yards) as of 01.01.2019. The highway passes through the village, which allows to connect important transport hubs between the regions: Struy-Lviv-Kirovograd-Znamyanka. On the territory of the collective farm. Shevchenko located 2591 hectares of land, including 1805 hectares of arable land. Since 2006, the lands have been leased from the agricultural firms of Zorya Podillya (https://vinrada.gov.ua/ ...). The population of Kunka territorial community table.1.

Table 1: Population of Kunka territorial community as of 01.01.2019, (persons)

\begin{tabular}{|c|l|c|}
\hline № & & Indicator value \\
\hline 1 & Population including: & 4376 \\
\hline 2 & - preschool age & 191 \\
\hline 3 & - school age & 345 \\
\hline
\end{tabular}

In the structure of the number of OTG residents, school and preschool children make up $-8.16 \%$.

One of the important tasks of the regulatory activity of the state in the basis of socioeconomic relations is to ensure the proper functioning and development of households, increasing the welfare of the population throughout the country. The subsistence level plays a significant role in solving tactical and strategic tasks of social protection of the population. Its use as an institution of social protection allows to influence the distribution of material goods and services and their consumption, to determine a 
number of macroeconomic proportions of social reproduction, to ensure the livelihood of the general population.

In the institutional and legal sense, the subsistence level is defined as a value sufficient to ensure the normal functioning of the human body, maintaining the health of a set of food and non-food products and a minimum set of services to meet basic social and cultural needs. The subsistence level has two forms of manifestation, each of which is determined by the structure of human needs.

According to the provisions of the Law of Ukraine of 15.07.1999 N 966-XIV "On the subsistence level", the subsistence level is a sufficient value to ensure the normal functioning of the human body, maintaining the health of a set of food and a minimum set of non-food items and the minimum set of services needed to meet the basic social and cultural needs of the individual (Law of Ukraine: On the State Budget of Ukraine for 2019 ...).

The subsistence level is determined by the normative method per month per person, as well as separately for those who belong to the main social and demographic groups:

- children under 6 years old;

- children aged 6 to 18 years;

- able-bodied persons;

- persons who have lost their ability to work.

The subsistence level is set annually by the Cabinet of Ministers of Ukraine and approved by the Verkhovna Rada of Ukraine upon adoption of the State Budget of Ukraine for the year. The subsistence level is the basic state standard, on the basis of which the state social guarantees and standards of the spheres of income of the population, housing and communal, household and social-cultural provision are determined.

In particular, the subsistence level for able-bodied persons is applied:

- when determining the amount of the official salary (tariff rate) of an employee of the 1 st tariff category as of January 1 of the calendar year;

- in determining the maximum amount of income that gives the right to apply social tax benefits;

- in determining the amount of social tax benefits for any taxpayer of personal income tax;

- when indexing wages.

Living wage refers to the established by laws, other normative legal acts of the social norms and standards, based on which we determined the levels of the basic state social guarantees. In this respect it is the objection that the Law of Ukraine "On state social standards and state social guarantees" the subsistence level is related to basic social standards. Can't be a standard minimum set of food products, social services, and the like, because it is contrary to the very notion of "standard". In particular our legislation quantifying a living wage unable to meet the basic social and cultural needs of the individual" and far from being able to contribute to improving the level and quality of life of our population. The subsistence minimum in the system of social protection is part of many complex indicators that reflect: the overall assessment of the level of living of the population of Ukraine and its regions, which is the basis for social policy and development of separate state social programs; determine the size of social assistance to 
families with children, unemployment benefits, as well as scholarships and other payments; it is the basis for determining eligibility for appointment of social assistance, state social guarantees and standards ensure that they are in the sectors of health, education, social services and others. As a result, he played a leading role in the implementation of state regulation of socio-economic processes, the impact on the deployment of certain phenomena in the sphere of social protection of the population, the determination of macroeconomic proportions of social reproduction.

Living wage - this is the category feature which in the monetary and natural form changes in the process of social development under the influence of the law of steady growth of the needs and growth of labor productivity, price dynamics, inflation, quantitative estimates of the range of consumer goods and services. Its level depends on the set of consumer values and services, which is taken in one country or another for at least material security, and calculated in prices of actual purchases. The volume of this set is determined by the economic capability of society, which depend on efficiency of functioning and development of the national economy, the policy of the state towards welfare and national traditions in the sphere of consumption, the mentality of the population. So a living wage is different in different countries of the world community and at different stages of their development. Usually he differential depending on the age, marital status and health status, place of residence of the person and so on.

Quantitative characteristics of the subsistence allowance in cash terms has two components. The first of these is the value of a selection of material benefits in the form of food, clothes, shoes, services provided, and the like. Because the requirements in these material benefits depends on the age, sex, disability person, he differential for basic social and demographic groups of the population. On the other hand, for the payment of the total expenditures of household members on the household needed cash. The cost of this component over its volume and the load on the total household income depends on the number of its members. Taking into account the first and the second component of household expenditure generated cost parameters of a living wage. In each period they depend on dynamics of prices for goods and services, the value of tariffs for housing and communal services, and other factors. The process of regulation of social policy through the instruments of the state Fig. 3.

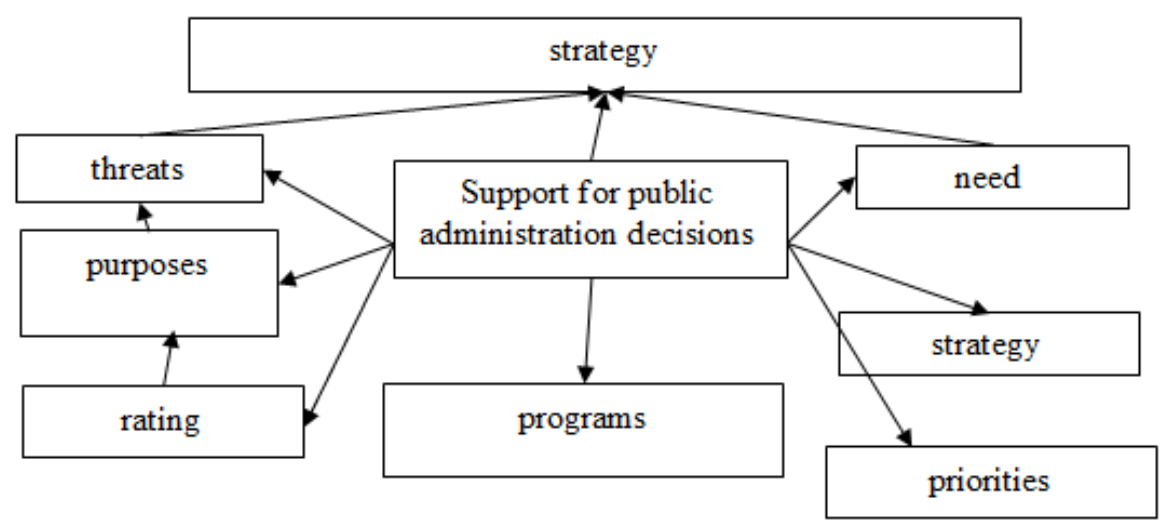

Fig. 3. The process of state regulation of social policy 
The subsistence level per year is determined by the Law of Ukraine "On the State Budget of Ukraine" each year. The size of the subsistence minimum per person from 2018 to 2020 is given in table 2 .

Table 2: The size of the subsistence minimum per person in 2018-2020, (UAH)

\begin{tabular}{|l|c|c|c|c|}
\hline Years & $\begin{array}{c}\text { Children under } \\
\text { 6 years }\end{array}$ & $\begin{array}{c}\text { Children aged } \\
\text { 6 to 18 years }\end{array}$ & $\begin{array}{c}\text { Able-bodied } \\
\text { persons }\end{array}$ & $\begin{array}{c}\text { Persons who have lost } \\
\text { their ability to work }\end{array}$ \\
\hline 01.01 .2018 & 1492 & 1860 & 1762 & 1373 \\
\hline 01.07 .2018 & 1559 & 1944 & 1841 & 1435 \\
\hline 01.12 .2018 & 1626 & 2027 & 1921 & 1497 \\
\hline $01.01-30.06 .2019$ & 1626 & 2027 & 1921 & 1497 \\
\hline $01.07-30.11 .2019$ & 1699 & 2118 & 2007 & 1564 \\
\hline $01.12-31.12 .2019$ & 1779 & 2218 & 2102 & 1638 \\
\hline $01.01-01.06 .2020$ & 1779 & 2218 & 2102 & 1638 \\
\hline $01.07-01.11 .2020$ & 1858 & 2318 & 2197 & 1712 \\
\hline December 2020 & $\underline{1921}$ & $\underline{2395}$ & $\underline{2270}$ & $\underline{1769}$ \\
\hline
\end{tabular}

Source (bttps:/ / wmw.profiwins.com.ua/ uk/ directories $1 /$ subsistence-minimum.html...)

Every year in the State budget are budgeted for the minimum payments to different categories of the population to maintain health, namely the smallest set of food, nonfoods and services. Payments for children up to 6 years will increase 295 UAH in 2020 - 1921 hryvnia in comparison, by 2018, or 18\%. Persons who are unable to work payments were made in 2018 at a level of $1497 \mathrm{UAH}$. which is $18.2 \%$ less set in the State budget 2020 and will amount to UAH 1769.

Payments to persons who work on 01.01.2018 year was 1762 UAH and on 01.01.2019 1921 UAH 159 UAH more (9\%). From the overall dynamics of the studied years, the conclusion is the following categories of persons in need of protection from the state are receiving payments from the budget and every year they increase. Another indicator that meets the vital human needs throughout the years is the market basket. On the basis of its content formed the subsistence minimum for different categories of the population table 3 .

Table 3: Food of the consumer basket in Ukraine 2017-2019, (kg)

\begin{tabular}{|c|c|c|c|c|c|c|c|c|c|c|c|c|}
\hline \multirow[t]{2}{*}{ Product name } & \multicolumn{3}{|c|}{$\begin{array}{c}\text { Children under } \\
6 \text { years }\end{array}$} & \multicolumn{3}{|c|}{$\begin{array}{c}\text { Children aged } \\
6 \text { to } 18 \text { years } \\
\end{array}$} & \multicolumn{3}{|c|}{$\begin{array}{l}\text { Able-bodied } \\
\text { persons }\end{array}$} & \multicolumn{3}{|c|}{$\begin{array}{l}\text { Persons who have lost } \\
\text { their ability to work }\end{array}$} \\
\hline & 2017 & 2018 & 2019 & 2017 & 2018 & 2019 & 2017 & 2018 & 2019 & 2017 & 2018 & 2019 \\
\hline Wheat bread & 29,2 & 29,2 & 29,2 & 51,1 & 51,1 & 51,1 & 62 & 62 & 62 & 62 & 62 & 62 \\
\hline Rye bread & 14,6 & 14,6 & 14,6 & 28 & 28 & 28 & 39 & 39 & 39 & 38 & 38 & 38 \\
\hline Wheat flour & 4,6 & 4,6 & 4,6 & 7.9 & 7.9 & 7,9 & 9,4 & 9,4 & 9,4 & 9,1 & 9,1 & 9,1 \\
\hline Pasta & 2,9 & 2,9 & 2,9 & 4,0 & 4,0 & 4,0 & 4 & 4 & 4 & 4,1 & 4,1 & 4,1 \\
\hline Rice groats & 1,3 & 1,3 & 1,3 & 1,8 & 1,8 & 1,8 & 2,5 & 2,5 & 2,5 & 2,3 & 2,3 & 2,3 \\
\hline Semolina & 0,9 & 0,9 & 0,9 & 1,2 & 1,2 & 1,2 & - & - & - & 0,9 & 0,9 & 0,9 \\
\hline Buckwheat & 2,4 & 2,4 & 2,4 & 3,4 & 3,4 & 3,4 & 2 & 2 & 2 & 2 & 2 & 2 \\
\hline Potato & 73 & 73 & 73 & 93,7 & 93,7 & 93,7 & 95 & 95 & 95 & 108 & 108 & 108 \\
\hline \begin{tabular}{|l|} 
Cabbage \\
\end{tabular} & 16,4 & 16,4 & 16,4 & 21,9 & 21,9 & 21,9 & 28 & 28 & 28 & 27,5 & 27,5 & 27,5 \\
\hline Tomatoes & 16,4 & 16,4 & 16,4 & 21,9 & 21,9 & 21,9 & 25 & 25 & 25 & 22 & 22 & 22 \\
\hline
\end{tabular}




\begin{tabular}{|l|c|c|c|c|c|c|c|c|c|c|c|c|}
\hline Carrot & 8.2 & 8.2 & 8,2 & 10,9 & 10,9 & 10,9 & 9 & 9 & 9 & 8 & 8 & 8 \\
\hline Beet & 6,6 & 6,6 & 6,6 & 8,7 & 8,7 & 8,7 & 9 & 9 & 9 & 8 & 8 & 8 \\
\hline Eggs & 6,0 & 6,0 & 6,0 & 7,9 & 7,9 & 7,9 & 220 & 220 & 220 & 187,5 & 187,5 & 187,5 \\
\hline Milk & 91,3 & 91,3 & 91,3 & 82,1 & 82,1 & 82,1 & 60 & 60 & 60 & 63 & 63 & 63 \\
\hline Fermented milk & 91,3 & 91,3 & 91,3 & 82,1 & 82,1 & 82,1 & 60 & 60 & 60 & 42 & 42 & 42 \\
\hline Cheese is hard & 1,8 & 1,8 & 1,8 & 4,3 & 4,3 & 4,3 & 3,5 & 3,5 & 3,5 & - & - & - \\
\hline Beef & 12,9 & 12,9 & 12,9 & 20 & 20 & 20 & 16 & 16 & 16 & 12,9 & 12,9 & 12,9 \\
\hline Bird & 5,8 & 5,8 & 5,8 & 9.2 & 9.2 & 9.2 & 14 & 14 & 14 & 5 & 5 & 5 \\
\hline Boiled sausage & 4,0 & 4,0 & 4,0 & 6,3 & 6,3 & 6,3 & 9 & 9 & 9 & 6.6 & 6.6 & 6.6 \\
\hline Fat & 1,0 & 1,0 & 1,0 & 1,5 & 1,5 & 1,5 & 2 & 2 & 2 & 2 & 2 & 2 \\
\hline The fish is fresh & 8,6 & 8,6 & 8,6 & 14,6 & 14,6 & 14,6 & 7 & 7 & 7 & 9,5 & 9,5 & 9,5 \\
\hline Herring & 4,2 & 4,2 & 4,2 & 7,3 & 7,3 & 7,3 & 4 & 4 & 4 & 0,7 & 0,7 & 0,7 \\
\hline
\end{tabular}

The required minimum composition of the consumer basket in Ukraine has remained unchanged since 2000, although the law provides for it to be updated every five years. The Cabinet of Ministers returned to the issue of reviewing the consumer basket in 2015 . In 2017, the government revised the composition of the consumer basket and made changes: updated the list of necessary medicines and hygiene products, increased the number of items of footwear and clothing. Table 4. presents the minimum sets of essentials, sanitation and medicines for 1 year.

Table 4: Essentials: sanitation and medicine in Ukraine 2017-2019

\begin{tabular}{|l|c|c|c|c|}
\hline \multirow{2}{*}{ Goods } & \multicolumn{3}{|c|}{ Year } & \multirow{2}{*}{ Expiration date } \\
\cline { 2 - 4 } & 2017 & 2018 & 2019 & 1 \\
\hline Laundry soap (250 g) & 11 & 11 & 11 & 1 \\
\hline Shampoo (250 g) & 2 & 2 & 2 & 1 \\
\hline Toothpaste & 6 & 6 & 6 & 1 \\
\hline Toothbrush & 4 & 4 & 4 & 1 \\
\hline Cologne & 1 & 1 & 1 & 1 \\
\hline Comb & 1 & 1 & 1 & 1 \\
\hline Cotton & 4 & 4 & 4 & 1 \\
\hline Bandage & 3 & 3 & 3 & 1 \\
\hline Corvalol, drops & 1 & 1 & 1 & 1,5 \\
\hline Thermometers, medical & 1 & 1 & 1 & 1 \\
\hline Adhesive plaster & 3 & 3 & 3 & 1 \\
\hline Antipyretics & 3 & 3 & 3 & 1 \\
\hline Analgin & 3 & 3 & 3 & \\
\hline
\end{tabular}

Source: (btp:// vingfu.gov.ual upload/files/bud file/ budjet2019.pdf...)

In addition to the above sets, the consumer basket of Ukraine also includes standards for nutrients for adults and children, a minimum set of clothes for men, women and children, textile linen, household goods, cultural, information and communication services, household and transport services. A large number of points indicates the high level of the country's economy. But some products are usually missing: drinks containing alcohol; delicacies; luxury items.

In developed countries, the composition of the consumer basket is determined according 
to the statistical data and the results of the survey population. For example, in the US set, what is included in the basket is determined by the budget Geller. That is, based on the goods and services that citizens consider essential for a full life. Thus, food products make up only $30 \%$ of the content of the basket. For comparison, in Ukraine food products make up almost $50 \%$. In many countries of Western Europe and the USA in the composition of the consumer basket provides for expenditure on food. For example, in Germany has the opportunity once a week to visit a café and order a pizza delivered to your house. The Kingdom laid in its basket champagne and beer. US citizens can also afford alcoholic drinks - beer, wine, whisky, both at home and in the restaurant (table 5). The analysis of the consumer basket of Ukraine and developed countries revealed differences in the articles of education, communication services, purchase of household appliances, laptops, computers and other equipment. In general, the Ukrainian consumer basket emphasizes the need to meet food needs and ensure a minimum livelihood. The needs for education and recreation are not taken into account.

Table 5: Elements of the consumer basket in different countries

\begin{tabular}{|l|c|c|c|c|c|c|c|}
\hline Country & $\begin{array}{c}\text { number } \\
\text { of items }\end{array}$ & food & alcohol & tobacco & education & $\begin{array}{c}\text { a personal } \\
\text { computer }\end{array}$ & $\begin{array}{c}\text { hairdressing } \\
\text { services }\end{array}$ \\
\hline Ukraine & 297 & + & - & - & - & - & - \\
\hline USA & 350 & + & + & + & + & + & + \\
\hline England & 350 & + & - & - & + & + & - \\
\hline France & 507 & + & - & - & - & + & + \\
\hline Georgia & 288 & + & + & - & - & - & - \\
\hline Belarus & 290 & + & - & - & - & - & - \\
\hline
\end{tabular}

One of the biggest problems of the social security system is the inefficiency of the domestic system of social benefits. For example, in Ukraine according to the effective legislation benefits available on the categorical principle, i.e. people get them as a result of belonging to one or other preferential categories of citizens. It does not take into account the income and wealth of beneficiary and his family, since the benefits in these categories are provided without prior verification of their income or means of subsistence, and the size of the benefits depends on the category of the recipient. As a result, the proportion of persons receiving social assistance, among those who do not belong to the poor according to the criterion of current income, even higher than the number of recipients among the poor. The total amount of benefits accounted for by households with average income greater than subsistence level. Certain categories of people receive benefits on many bases over a long period of time without assessment of the need for them. The amount of aid received "poor" and "non-poor", practically does not differ. Because benefits are largely provided regardless of income and needs (from which the poorest), they can provide the poor a living wage. Compounding the problem is that the access to benefits in the country is extremely uneven: the proportion of urban families using privileges on payment of transport services, three times higher than the rural population $(12.6 \%$ and 30,9\%). A significant number of privileged categories of persons has led to the fact that almost a third of the population of Ukraine for covered benefits. According to the legislative acts the right to benefits are 19.5 million citizens, 
representing more than $1 / 3$ of the population of Ukraine.

The main categories of citizens who are entitled to benefits include: labor veterans (about 4.9 million people), of whom people who have special merits to the homeland (1.1 thousand); war veterans (about 3.3 million people); victims of the Chornobyl disaster (about 2.1 million); children of war (6.7 million); persons entitled to benefits on professional (official) grounds (about 1.3 million); participants of the anti-terrorist operation and the Revolution of Dignity (5.4 million); old-age pensioners (10.6 million). In addition, one person can receive several statuses that entitle him to benefits, surcharges, preferences, benefits, and so on.

The large number of persons entitled to benefits, as well as their relatively large size, lead to the inability of state funds to finance them in full. Thus, the Ministry of Social Policy reports that in general, about UAH 30-33 billion has been set aside in the state budget for 2018 for the payment of all state social benefits, privileges, compensations and preferences. In general, UAH 6079781.6 thousand was allocated for social security in Vinnytsia region in 2017, which is UAH 78721.3 thousand less than in 2016. But if we calculate the total number of benefits that exist in the current legislation, then for their maintenance requires an amount that is equal to the amount of about half of the state budget - almost 120 - 140 billion hryvnia. That is, there is an increase in liabilities for benefits without adequate sources of funding. Payments of the State Budget of Vinnytsia region for social protection of the rural population and certain categories of citizens in 2017 amounted to - 6079781.6 thousand UAH, and in 201811596316.2 thousand UAH. table 6.

Table 6: Payments of the State budget for social protection of the population of Vinnytsia region in 2017-2019 (thousand UAH)

\begin{tabular}{|c|c|c|c|c|}
\hline \multirow{2}{*}{ Indicators } & \multicolumn{3}{|c|}{ Years } & \multirow{2}{*}{$\begin{array}{c}\text { Deviation } \\
(+,-)\end{array}$} \\
\hline & 2017 & 2018 & 2019 & \\
\hline $\begin{array}{l}\text { Subventions: payment of assistance to families with } \\
\text { children, low-income families, children with disabilities } \\
\text { from childhood, children with disabilities; }\end{array}$ & 2093117,7 & 2076310,4 & 2551136,1 & $+458018,4$ \\
\hline $\begin{array}{l}\text { providing benefits and housing subsidies to the } \\
\text { population to pay for electricity, natural gas, heat, water } \\
\text { supply and sewerage services, rent, removal of } \\
\text { household waste and liquid sewage; }\end{array}$ & 3423059,9 & 3497827,3 & 1763260,6 & $-1659793,3$ \\
\hline $\begin{array}{l}\text { providing benefits and housing subsidies to the } \\
\text { population for the purchase of solid and liquid furnace } \\
\text { household fuel and liquefied gas }\end{array}$ & 268039,4 & 230604,9 & 300336,2 & $+32296,8$ \\
\hline $\begin{array}{l}\text { payment of monetary compensation for adequate } \\
\text { accommodation for internally displaced persons who } \\
\text { defended the independence, sovereignty and territorial } \\
\text { integrity of Ukraine and took a direct part in the anti- } \\
\text { terrorist operation }\end{array}$ & - & 3398,9 & 14637,3 & $+11238,4$ \\
\hline Total & 5784217 & 58081415 & 4633370,2 & \\
\hline
\end{tabular}

Subventions of the State budget for social payments to the population were variable every year, so payments to low-income families increased by 458018.4 thousand UAH. against 2017. But the provision of benefits and housing subsidies to the population to pay for electricity, natural gas decreased in 2019 by -1659793.3 thousand UAH compared to 2017. The total amount of revenues of the regional budget as of 01.01 .2019 is 9434592671,00 
UAH, the total amount of expenditures of the regional budget - 9 415578276,00 UAH. The structure of revenues of the general fund of the regional budget for 2017-2019 thousand UAH Figure 4.

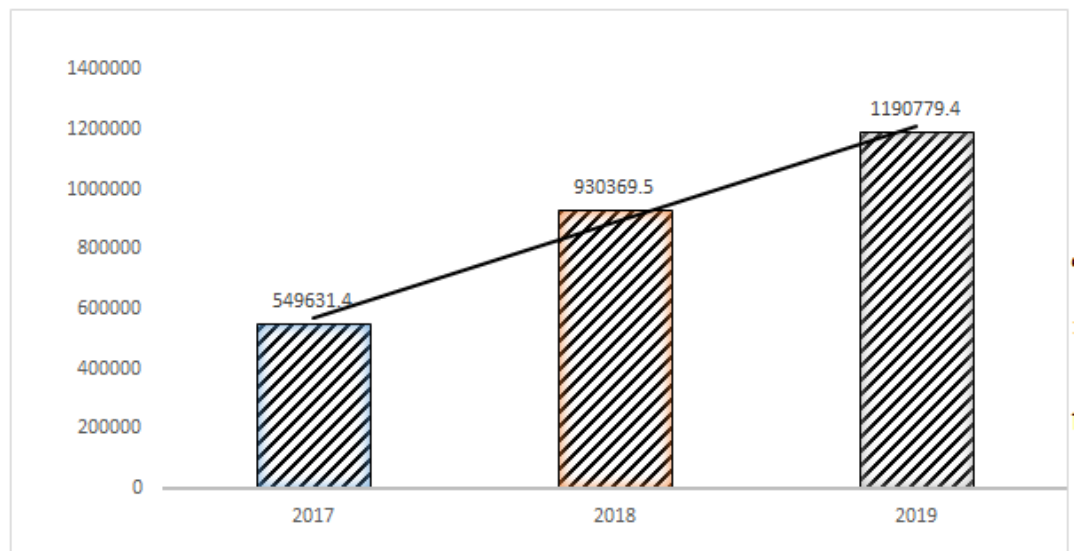

Fig.4. Structure of revenues of the general fund of the budget of Vinnytsia region 2017-2019, (thousand UAH)

In the structure of budget revenues of the region, we see a steady increase, so in 2019 revenues amounted to - 1190779.4 thousand UAH, which is 260409.9 thousand UAH more against $2018(4.6 \%)$.

In terms of districts of Vinnytsia region, we can observe a tendency to increase revenues of local budgets. Thus, in 2017, among the first united territorial communities, Kalynivka received income totaling UAH 55,972.7 thousand, and in 2019 - 100,628.2, which is $1.8 \%$ more. The growth of the local budget revenue of Haisyn district took place by $1.34 \%$, or by UAH 54,241.1 thousand in 2019 compared to 2017. There is also a decrease in local budget revenues in Illinetsky district, which is - 75430.6 thousand UAH in 2017, the total income of 30242.2 thousand UAH in 2018 and UAH 26,440.0 thousand - 2019, respectively, table 7 .

Table 7: Receipts of revenues of the general fund of local budgets of Vinnytsia region 2017 - 2019, (thousand UAH)

\begin{tabular}{|c|l|c|c|c|c|}
\hline \multirow{2}{*}{$№$} & \multirow{2}{*}{ Name of the district, city } & \multicolumn{3}{|c|}{ Years } & Deviation \\
\cline { 2 - 5 } & & 2017 & 2018 & 2019 & $(+,-)$ \\
\hline 1 & Gaisinsky & 159086,0 & 229108,2 & 213327,1 & $+54241,1$ \\
\hline 2 & Zhmerynsky & 43743,7 & 68411,6 & 73387,3 & $+29643,6$ \\
\hline 3 & Illinetsky & 75430,6 & 30242,2 & 26440,0 & -48990 \\
\hline 4 & Kalinovsky & 57898,6 & 101051,9 & 99404,5 & +415059 \\
\hline 5 & Kozyatynsky & 55490,8 & 115442,7 & 119899,8 & +64409 \\
\hline 6 & OTG Kalinovka & 55972,7 & 87512,1 & 100628,2 & $+44655,5$ \\
\hline 7 & OTG Studena & 5998,5 & 9376,8 & 11735,7 & $+5737,2$ \\
\hline 8 & Khmelnytsky & 66403,7 & 88228,4 & 105112,4 & $+38708,7$ \\
\hline 9 & Yampilsky & 57373,8 & 93751,4 & 109805,1 & $+51431,3$ \\
\hline 10 & Chechelnytsky & 30615,3 & 52074,0 & 59395,1 & $+28779,8$ \\
\hline 11 & Shargorodsky & 60533,7 & 112257,2 & 127452,9 & $+66919,2$ \\
\hline
\end{tabular}


In 2018, the consolidated budget of the region (general and special funds) incurred expenditures in the amount of UAH 22,920.1 million, which is $97.5 \%$ of the plan for the year, taking into account changes (planned UAH 23,499.5 million) and increased against 2017 by UAH 2,835.9 million, or by 14.1\%. Of these, development expenditures amounted to UAH 3,061.6 million, which is $86.2 \%$ of the plan for the year, taking into account changes (planned UAH 3,551.4 million), which is more than in 2017 by UAH 190.4 million. UAH, or by $6.6 \%$.

First of all, the budget funds were used to finance the socio-cultural sphere: in 2018, UAH 17,542.8 million was used for these purposes. - this is $76.5 \%$ of all expenditures of general and special funds. Of these, UAH 6,657.1 million was used for education. (against 2017, an increase in comparable conditions by UAH 1,184.6 million, or 21.1\%), for health care - UAH 3,646.2 million. (increase compared to 2017 by UAH 62.2 million, or by $1.7 \%$ ), for social protection and social security - UAH 6,513.1 million. (increased by UAH 185.4 million or $2.9 \%$ ), for culture - UAH 523.4 million. (increase in comparable conditions by UAH 72.7 million, or by $16.1 \%$ ), for physical culture and sports - UAH 203.0 million. (increase by UAH 42.0 million or by $26.1 \%$ ).

In addition, in 2018 in the housing and utilities used 815,8 million UAH. (against the same period last year, an increase of 37.4 million, or $4.8 \%$ ), construction - 1087,3 million. (increase vs 2017 on of 312.9 million, or 40.4\%), the maintenance and development of highways - 1088,1 million. (increased vs 2017 on 713,2 million UAH. or 2.9 times). In particular, in 2018, the 18424,1 million general fund, accounting for $97.8 \%$ of plan for the year taking into account changes (planned 18 836,1 million.) against 2017 increased by 2064,7 million, or 12.6\%. Basically secured financing of protected articles of expenditures, in particular completeness and timeliness of payment of wages and salaries, payments for the consumed energy, payments for social security (stipends, social pensions, etc.). Budgetary discipline and sound financial policy is the key to the coordinated activities of all institutions that are fixed in the plan for the future development of the region in the years 2019-2021.

According to paragraph 17 of part 1 of article 43 of the Law of Ukraine "About local government in Ukraine" and article 77 of the Budget code of Ukraine, taking into account the motion of the regional state administration and the conclusions of the constant Commission of regional Council on budget, Finance and regional programs, the regional Council decided to establish the total expenditure in terms of regions of Vinnytsia region. Subventions from the regional budget to local budgets in recent years was carried out not uniformly. A large share of expenditure on social security of the needy layers of the population of the state social allowances for orphaned children and children deprived of parental care, etc. in the amount of 997,000 thousand hryvnias in 2019 , and це $1,95 \%$ of the total intergovernmental transfers Vinnytsia regional budgets amount to $1972585,00 \mathrm{UAH}$ the data is given in table 8 testify to the above. 
Table 8: Interbudgetary transfers from Vinnytsia regional budget for social needs to Haisyn district 2017-2019 (thousand UAH)

\begin{tabular}{|l|c|c|c|}
\hline \multirow{2}{*}{ Subventions } & \multicolumn{2}{|c|}{ Years } \\
\cline { 2 - 4 } & 2017 & 2018 & 2019 \\
\hline $\begin{array}{l}\text { payment of assistance to families with children, low-income } \\
\text { families, persons with disabilities, children with disabilities }\end{array}$ & 63511,300 & 70987,600 & 74678,100 \\
\hline $\begin{array}{l}\text { state social benefits for orphans and children deprived of parental } \\
\text { care, cash benefits }\end{array}$ & 886,300 & 936,000 & 997,000 \\
\hline $\begin{array}{l}\text { providing benefits and housing subsidies to the population to pay } \\
\text { for electricity, natural gas, heat and water supply services }\end{array}$ & 131585,800 & 148905,700 & 89749,200 \\
\hline targeted expenditures for the treatment of patients with diabetes & $-/ /-$ & 795,621 & 754,000 \\
\hline to reimburse the funeral expenses of combatants and war invalids & $-/ /-$ & 16486 & 4,657 \\
\hline
\end{tabular}

\section{Conclusions}

This should take into account a number of important points.

1. The transfer of control of the assets of the social insurance non-state insurance funds will require significant attention to the problems of the reliability of the latter, improving the efficiency of their use. Unfortunately, Ukraine has not yet formed the proper business and professional ethics of an open, efficient business, especially in the financial sector. So fundamentally important prerequisites for the establishment of an effective system of social insurance is formation of developed transparent stock market and the implementation of effective control over implementation of economic legislation. This indicates the impossibility of a rapid transition of the social security insurance principles, and requires phasing of this process.

2. The transition to the payment of the single social contribution and the reduction of the social tax burden on the wage fund should be made. Currently, the total amount of social insurance contributions is $41.7 \%$ of the wage bill, with $38.7 \%$ paid by employers and $3 \%$ by insured persons. It is estimated that the introduction of compulsory health insurance in favor of the health care system will require a redistribution of about $3 \%$ of gross domestic product, which corresponds to an increase in total insurance premiums by an additional $5 \%$ of the payroll. This situation encourages employers to hide the real amount of the wage fund, which in the transition to social security insurance provides the basis for conflict between employers and employees.

3. Integration of all types of social insurance into one system will cover the risks of a distant period (pensions) and the risks of everyday life (health insurance), increasing "consumer demand" for the social insurance system. This will create appropriate conditions for the emergence of the social pressure on employers who evade the payment of contributions to compulsory social insurance. In turn, this will affect the General level of insurance premiums payable and, accordingly, will lead to some extension of the consolidated assessment base of compulsory insurance. The introduction of the single social contribution requires a gradual and balanced approach to its implementation. Indeed, in terms of reforming the pension system to significantly increase the cost of the joint system, and the introduction of a unified social contribution should not entail reducing the level of financial income.

Therefore, the introduction of a single social contribution should be accompanied by a reduction in administrative costs and an increase in the efficiency of social funds. At the 
same time, the main achievements of the current system should be preserved: the insurance principle of financing, separation of fund budgets, parity of participation of social partnership parties in their management, publicity, transparency and accessibility of social insurance for all segments of the population.

An important prerequisite for improving the efficiency of the social protection system is the implementation of calculations regarding the forecasting of costs for the implementation of a set of measures under these programs and evaluation of the effectiveness of their implementation. This requires the development of methodological principles for the control of social protection programs, taking into account their focus, targeting, level of implementation and other leading characteristics.

\section{References}

Bazilevich V. D. Bazilevich, K. S., Balestri L. A. Macroeconomics: Textbook. Kiev: Knowledge, 2004. 743 p.

Boretskaya N. P. Social protection of the population at the present stage: state and problems. Monograph. Donetsk. Amber. 2001.

Kulichuskuy B.V. The modern economic system. Textbook. Lviv: Afisha, 2004. 279 p

On the State budget of Ukraine to 2019: Law of Ukraine from 23.11.2018, No. 2629-VIII. Kiev: The Supreme Council of Ukraine, 2019.

Constitution of Ukraine of 28.06.1996, № 254к/96-VR. Kiev: The Supreme Council of Ukraine, 1996. 141 p.

On obligatory state social insurance in connection with temporary disability and expenditures caused by birth and burial: Law of Ukraine from 18.01.2001 No. 2240-III. Kiev: The Supreme Council of Ukraine, 2001.

On compulsory state social insurance in case of unemployment: Law of Ukraine of 02.03.2000. No. 1533-III. Kiev: Supreme Council of Ukraine, 2000.171 p.

L. Pronko, T. Kolesnik, O. Samborska Ukraine Dairy Market: State and Prospects of Development. European Journal of Sustainable Development (2020), 9, 1, pp. 243-252. 